\title{
Analisis Pergeseran Titik Jaring Pemantau Candi Borobudur Mengacu ke ITRF 2008 Berdasarkan Data Pengamatan GPS pada Tahun 2003 dan 2012
}

\section{Point Displacement Analysis of Candi Borobudur Monitoring Network refer to ITRF 2008 Based on GPS Observation Data in 2003 and 2012}

\author{
Dwi Lestari' ${ }^{1}$, Bondan Galih Dewanto ${ }^{2,3}$
}

1 Staf Pengajar Departemen Teknik Geodesi FT-UGM, Indonesia

2 Alumni Departemen Teknik Geodesi FT-UGM, Indonesia

${ }^{3}$ Center for Disaster Studies, Universitas Gadjah Mada, Yogyakarta, Indonesia

Penulis Korespondensi: Bondan Galih Dewanto | Email: bondan.galih.d@mail.ugm.ac.id

Diterima (Received): 07/10/2020 Direvisi (Revised): 05/11/2020 Diterima untuk Publikasi (Accepted): 09/11/2020

\begin{abstract}
ABSTRAK
Pemantauan posisi Candi Borobudur bertujuan untuk menjaga warisan dunia. Salah satu caranya adalah dengan pembangunan bench mark (BM) atau titik kontrol untuk pemantauan deformasi menggunakan Global Positioning System (GPS). Pengukuran menggunakan teknologi GPS untuk pemantauan stabilitas Candi Borobudur telah dilakukan pada tahun 2002, 2003, dan 2012, menggunakan Global Kalman Filter VLBI dan analisis GPS dan mengacu pada ITRF2000 untuk menganalisis pergeseran horisontal. ITRF menuntut pemutakhiran data koordinat titik-titik kontrol secara periodik. Perbedaan penggunaan versi ITRF pada pengolahan data GPS berdampak pada perbedaan ketelitian estimasi posisi, besar kecepatan dan arah pergeseran titik-titik kontrol. Tujuan dari penelitian ini adalah untuk mengukur estimasi posisi, kecepatan, dan arah pergerakan dari titik control GPS berdasarkan data 2003 dan 2012 dan mengacu pada ITRF2008. Masing-masing kala melalui tahapan regional processing dan local processing. Koordinat dari hasil local processing GAMIT/GLOBK selanjutnya dibandingkan dengan koordinat hasil olahan mengacu ITRF2000 yang telah ditransformasi menjadi koordinat mengacu ITRF2008. Analisis pergeseran titik berdasarkan koordinat dan hasil dari data 2003 dan 2012. Penelitian ini menghasilkan bahwa perbedaan posisi dan akurasi pada pengolahan regional dan lokal mengindikasikan transformasi dari ITRF2000 ke ITRF2008 berada pada standar deviasi yang dihasilkan GAMIT dan GLOBK yang mengacu pada ITRF2008. Selanjutnya, rata-rata nilai pergeseran horisontal periode 2003 dan 2012 adalah $261 \mathrm{~mm}$ arah tenggara (SE) yang serupa dengan penggunaan ITRF2000 pada penelitian sebelumnya. Secara umum, perataan jaring Candi Borobudur yang mengacu pada ITRF 2008 lebih akurat dibandingkan penelitian sebelumnya yang mengacu pada ITRF2000.
\end{abstract}

Kata Kunci: Deformasi, Borobudur, Earth Crustal, Akurasi, GNSS, Kecepatan, GAMIT/GLOBK

\section{ABSTRACT}

Monitoring Borobudur temple's position is an attempt to maintain one of the world's heritage. Measurement using GPS in order to observe Borobudur temple's stability had been done at 12 points in 2002, 2003, and 2012, using GPS Analysis and referring to ITRF2000 to analyze the horizontal movement. The difference resulted from the use of ITRF in GPS data processing has an effect of the accuracy in analysis of the GPS control points. The purpose of this research is to measure the position estimation, velocity, and the movement direction of the GPS control points based on data 2003 and 2012 referring to ITRF 2008. The process has been gone through regional and local processing. The coordinates acquired from GAMIT/GLOBK local processing is compared with coordinates based on ITRF2000 which has been transformed to ITRF2008. Point displacement analysis are based on the coordinates and data results from 2003 and 2012. This study stated that the difference in position and its accuracy in both regional and local processing indicates that all the transformed values from ITRF 2000 to ITRF 2008 are still within the range of two sigma level of the GAMIT and GLOBK results referred to ITRF2008. Furthermore, the mean of horizontal displacement value for the period 2003 and 2012 was $261 \mathrm{~mm}$ in the southeast (SE) direction which similar to the use of ITRF2000 in previous study. In general, the Borobudur temple network adjustment referring to the ITRF 2008 was more accurate compared to the previous studies which referred to ITRF2000.

Keywords: Deformation, Borobudur, Earth Crustal, Accuracy, GNSS, Velocity, GAMIT/GLOBK

(c) Author(s) 2020. This is an open access article under the Creative Commons Attribution-ShareAlike 4.0 International License (CC BY-SA 4.0). 


\section{Pendahuluan}

Indonesia merupakan negara yang memiliki sejarah kebudayaan yang panjang. Beberapa contoh hasil dari sejarah ini adalah dengan berdirinya Candi Borobudur dan Candi Prambahan. Sebagai warisan budaya dunia, candicandi tersebut perlu dijaga kelestarianya karena nilai sejarah yang terdapat pada candi. Salah satu upaya merawat candi adalah dengan memantau stabilitas tanah dan struktur bangunan candi secara geometrik menggunakan metode geodetik.

Metode geodetik yang telah dilakukan diantaranya adalah dengan pembangunan bench mark (BM) atau titik kontrol untuk pemantauan deformasi menggunakan Global Positioning System (GPS). Pembangunan BM telah dilakukan melalui kerjasama antara Jurusan Teknik Geodesi FT UGM dengan Balai Konservasi Borobudur (BKB) pada tahun 2000. Titik BM yang dibangun di Candi Borobudur berjumlah sembilan (Ma'ruf, dkk., 2001). Sedangkan pada kasus Candi Prambanan, pemantauan menggunakan GPS pertama kali dilakukan oleh Muryamto dkk (2018) dengan pembangunan lima titik BM.

Pengukuran dan studi pemanfaatan teknologi GPS untuk pemantauan stabilitas Candi Borobudur telah dilakukan pada tahun 2002, 2003, dan 2012 (Lestari, 2015). Jumlah titik yang diamat sebanyak 12 titik. Posisi dan laju perubahan posisi titik-titik GPS pada studi tersebut dinyatakan dalam sistem koordinat 3D di atas elipsoid referensi World Geodetic System 1984 (WGS 84), dihitung mengacu pada kerangka acuan global International Terestrial Reference Frame 2000 (ITRF 2000). Hasil analisis pergeseran dengan GLOBK (Global Kalman Filter VLBI and GPS Analysis) menggunakan kerangka acuan ITRF2000 pada tingkat kepercayaan 95\% (Herring dkk, 2015), diketahui bahwa penambahan kala pengamatan GPS tahun 2012 pada solusi gabungan terbukti meningkatkan ketelitian estimasi posisi dan vektor kecepatan pergeseran horizontal. Pergeseran horizontal berdasarkan data pengamatan GPS dipengaruhi oleh faktor internal dan eksternal. Vektor kecepatan pergeseran horizontal rerata yang diperoleh adalah $29 \mathrm{~mm} / \mathrm{thn}$ dengan arah pergeseran ke tenggara, konsisten dengan pergerakan tektonik di Pulau Jawa (Lestari, 2015). Penelitian Isnaini dan Lestari (2018) mengunakan time-variant adjustment, memperlihatkan kenaikan vector kecepatan pergeseran horizontal dari $29 \mathrm{~mm} /$ thn menjadi $32 \mathrm{~mm} / \mathrm{thn}$. Sedangkan untuk vektor kecepatan pergeseran vertikal, metode timevariant adjustment digunakan untuk memantau epoch tahun 2003 dan 2004, menunjukkan penurunan rerata sebesar 4,229 mm dengan simpangan baku senilai 0,597 mm (Lestari dkk, 2018).

Pengukuran jarak pada saat pengamatan dan pengukuran menggunakan teknologi GPS dibagi menjadi dua jenis (Widjajanti, 2010) yaitu pengukuran pseudorange dan carrier phase. Bias dalam pengukuran GPS dapat bergantung pada beberapa faktor yaitu bergantung pada satelit, receiver, dan receiver-satelit. Pengolahan data GPS umumnya dilakukan secara post-processing untuk memperoleh ketelitian yang lebih tinggi (Abidin, 1995). ITRF merupakan kerangka referensi geospasial global sebagai realisasi dari ITRS (The International Terrestrial Reference System) (Fahrurrazi, 2011). Koordinat jaring stasiun ITRF merealisasikan origin dan orientasi sumbu koordinat geodetik yang senantiasa bergerak karena gerakan lempeng tektonik sehingga koordinatnya juga senantiasa berubah secara dinamis dengan pola (besar dan arah) yang bervariasi antara satu titik dengan titik yang lain ITRF2000 memiliki sekitar 800 stasiun yang terletak pada sekitar 500 situs (Boucher, dkk, 2004). ITRF2008 merupakan perbaikan dari ITRF2000 (Altamimi, dkk, 2012) dan perbaikan terakhir dari ITRS adalah ITRF2014 didemonstrasikan memiliki kualitas lebih tinggi dibandingkan dengan versi ITRF yang lebih lama dan dilengkapi dengan model nonlinear pergerakan stasiun (Altamimi, dkk, 2016).

Pada studi ini ITRF digunakan sebagai kerangka acuan dalam penentuan posisi titik-titik pengamatan GPS, sehingga posisi titik-titik GPS dapat disatukan dalam satu sistem referensi global. Perbedaan penggunaan versi ITRF pada pengolahan data GPS berdampak pada perbedaan ketelitian estimasi posisi, besar kecepatan dan arah pergeseran titik-titik kontrol. Pengolahan data GPS mengacu pada ITRF terbaru menghasilkan tingkat akurasi yang lebih baik (Wei, dkk., 2013). Wei dkk (2013) melakukan penelitian perbedaan penggunaan ITRF2000 dan ITRF2005 pada pengolahan data GPS. Saat ini Indonesia menetapkan ITRF 2008 sebagai kerangka acuan untuk jaring nasional (SRGI 2013). Makalah ini mendiskusikan kajian pengaruh penggunaan ITRF 2008 pada akurasi analisis deformasi jaring GPS pada pemantauan Candi Borobudur.

\section{Data dan Metodologi (Cambria, 11 pt, bold)}

2.1. Data dan Lokasi (Cambria, $10 \mathrm{pt}$ )

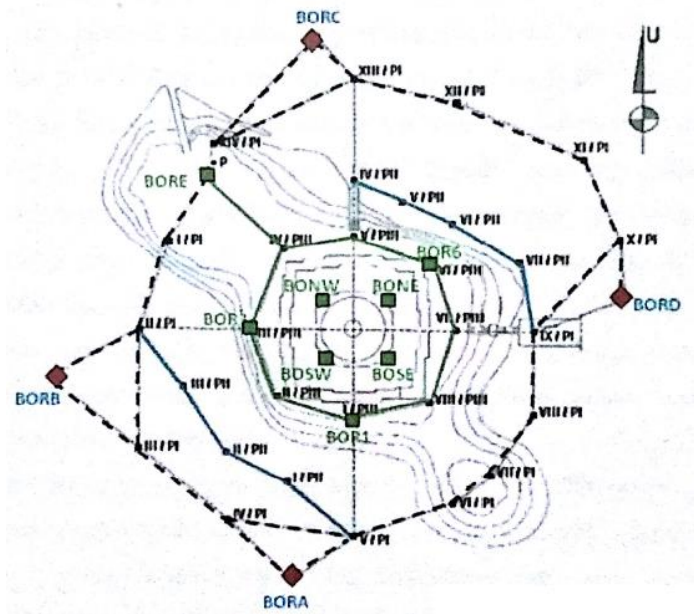

Gambar 2.1. Sketsa distribusi titik-titik kontrol GPS Candi Borobudur (Lestari, 2015) 
Data yang digunakan pada studi ini berupa data ukuran hasil pengamatan GPS di 12 titik jaring GPS Borobudur tahun 2003 dan 2012. Titik-titik tersebut adalah BORA, BORB, BORC, dan BORD berada di taman candi,titik BORE, BOR1, BOR3, dan BOR6 berada di halaman candi, sertatitik BONE, BOSE, BONW, dan BOSW merupakan titik yang berada di lorong stupa (Lestari, 2015). Distribusi titik-titik kontrol GPS dijelaskan pada Gambar 2.1. Karakteristik data pengamatan bisa dijelaskan di sini.

\subsection{Pengolahan Data}

Pengolahan data dimaksudkan untuk mendapatkan posisi titik-titik pantau GPS tahun 2003 dan 2012 mengacu pada ITRF 2008 serta vektor kecepatan perubahan posisi antara kedua waktu tersebut. Pengolahan data dilakukan menggunakan perangkat ilmiah GAMIT 10. Sesuai dengan tujuan penelitian ini untuk melihat pengaruh penggunaan kerangka acuan yang berbeda pada analisis deformasi Candi Borobudur, maka skenario pengolahan data tetap merujuk pada Lestari (2015) dengan update pada penggunaan kerangka acuanya menjadi ITRF 2008. Pengolahan data pada penelitian ini dibagi menjadi dua tahap, yaitu regional processing dan local processing. Secara skematis tahapan pengolahan data dijelaskan pada Gambar 2.2. Pada gambar tersebut, $\mathrm{X}, \mathrm{Y}$, dan $\mathrm{Z}$ merupakan posisi dalam system koordinat kartesi 3D. Sedangkan $\sigma_{\mathrm{x}}, \sigma_{\mathrm{y}}$, dan $\sigma_{\mathrm{z}}$ adalah simpangan baku posisi $\mathrm{X}, \mathrm{Y}$, dan $\mathrm{Z}$, secara berurutan. Vx, Vy, Vz adalah laju pergeseran posisi titik.

Regional processing bertujuan untuk mendapatkan posisi ketelitian titik-titik jaring GPS di taman, yaitu titik BORA, BORB, BORC, dan BORD relatif terhadap kerangka acuan global dengan mengikutkan beberapa stasiun IGS, yaitu stasiun BAKO, NTUS, PIMO, COCO, KARR, dan DARW yang dapat diunduh melalui http://garner.ucsd.edu. Pengikatan terhadap stasiun IGS digunakan sebagai connected point dalam pembentukan multibaseline pada daily processing.

Sedangkan local processing bertujuan untuk menentukan koordinat di halaman (BORE, BOR1, BOR3, dan BOR6) dan lorong stupa (BONE, BOSE, BONW, dan BOSW), mengacu pada titik BORA, BORB, BORC, BORD yang sudah ditentukan sebelumnya. Perbedaan skema regional processing dan local processing dapat dilihat pada Tabel 2.1.

Tabel 2.1. Skema pengolahan jaring Borobudur

\begin{tabular}{llll}
\hline \multicolumn{1}{c}{ Perbedaan } & \multicolumn{2}{c}{$\begin{array}{c}\text { Regional } \\
\text { Processing }\end{array}$} & \multicolumn{2}{c}{$\begin{array}{c}\text { Local } \\
\text { Processing }\end{array}$} \\
\hline Koordinat titik & BORA, BORB, & BORE, & BOR1, \\
yang dituju & BORC, BORD & BOR3, & BOR6, \\
& & & BONE, BOSE, \\
& & & BONW, BOSW \\
\hline Titik Pengikat & BAKO, NTUS, & BORA, BORB, \\
& PIMO, COCO, & BORC, BORD \\
& KARR, dan & & \\
& DARW & & \\
& &
\end{tabular}

\subsection{Pengolahan data multi kala}

Pengolahan data multi kala ini untuk mengkombinasikan hasil pengukuran GPS tahun 2003 dan 2012 (atau disebut dengan combined solution) untuk mendapatkan estimasi posisi rerata serta vektor laju perubahan posisi titik-titik jaring pengamatan GPS di Borobudur. Proses dilakukan menggunakan GLOBK dengan input $h$-files hasil pengolahan GAMIT harian untuk tahun 2003 dan 2012. Tahapannya juga dibedakan untuk regional processing dan local processing, karena data yang digunakan multi kala, sehingga juga dilakukan estimasi laju (rate) vektor perubahan posisi 3D.

Solusi gabungan dengan globk (globk combined solution) pada regional processing untuk mengetahui stabilitas empat titik-titik GPS di taman. Langkah prosedurnya didahului dengan menyiapkan $h$-files dalam format binary, apriori file, dan file perintah (command file) yang mengatur tipe solusi yang digunakan, parameter yang diestimasi, dan kendala yang diterapkan.

Hasil dari solusi gabungan seperti yang dijelaskan tersebut adalah estimasi posisi titik-titik GPS dan vektor kecepatan perubahan posisinya beserta ketelitian masingmasing. Hasil estimasi untuk titik-titik GPS di Borobudur (BORA, BORB, BORC, dan BORD) kemudian dijadikan nilai apriori yang baru yang digunakan sebagai acuan pada proses combined solution untuk local processing (Lestari, 2015).

Proses globk combined solution untuk local processing tidak seperti regional processing, yaitu tidak melibatkan titik kontrol dari stasiun global untuk orientasi jaring GPS Borobudur ke dalam sistem ITRF. Tahapan proses disini sama dengan combined solution pada regional processing, yang membedakan adalah pada tahap ini tidak melibatkan $h$-files dari solusi global, serta parameter orbit dibuat fixed. Perbedaan tersebut terangkum dalam perintah-perintah untuk menjalankan globk, glred, dan glorg, seperti dijelaskan pada perintah GLOBK pada local processing per tahun.

\subsection{Analisis Hasil}

Analisis dilakukan pada hasil pengolahan jaring pemantau Candi Borobudur tahun 2003 dan 2012 mengacu ITRF 2008 (Dewanto, 2016). Sebelum diolah, diperlukan pengecekan parameter evaluasi GAMIT/ GLOBK. Parameter evaluasi GAMIT meliputi postfit nrms dan fract, sedangkan parameter evaluasi GLOBK adalah plot time series dari hasil pengolahan data harian. Masing-masing kala diawali dengan regional processing dengan tahapan pengolahan GAMIT, GLRED, lalu GLOBK. Hasil pengolahan berupa koordinat dari regional processing kemudian digunakan sebagai koordinat apriori pada local processing. Tahapan yang dilakukan pada local processing sama dengan regional processing. Hasil akhir koordinat titik pemantau Candi Borobudur yang digunakan adalah hasil dari local processing.

Koordinat dari hasil local processing GAMIT/GLOBK selanjutnya dibandingkan dengan koordinat hasil olahan mengacu ITRF 2000 (Lestari, 2015) yang telah ditransformasi menjadi koordinat mengacu ITRF 2008. Proses ini bertujuan untuk mengetahui seberapa besar pengaruh perbedaan koordinat hasil pengolahan perangkat lunak GAMIT/GLOBK pada penelitian ini dengan hasil transformasi. Selain menggunakan data masing-masing 
kala, analisis dilakukan pula terhadap data pengamatan multi kala tahun 2003 dan 2012. Koordinat posisi pada setiap kala mempunyai tingkat ketelitian yang bervariasi. Ketelitian koordinat posisi titik disajikan dalam bentuk grafik untuk mengetahui perbandingan setiap kala.

Berdasarkan koordinat hasil pengolahan data 2003 dan 2012 mengacu pada ITRF 2008 dilakukan analisis pergeseran antar kala. Analisis ini menghasilkan besaran pergeseran serta arah pergeseran yang terjadi pada tiap titik pengamatan pada jaring pemantau Candi Borobudur.

Pada penelitian ini dilakukan pula uji signifikansi pergeseran titik pengamatan GPS. Hasil akhir dari proses uji signifikansi adalah diketahuinya seberapa besar perbedaan posisi masing-masing titik pengamatan jaring pemantau Candi Borobudur antara 2003 dan 2012 mengacu pada ITRF 2000 dan ITRF 2008.

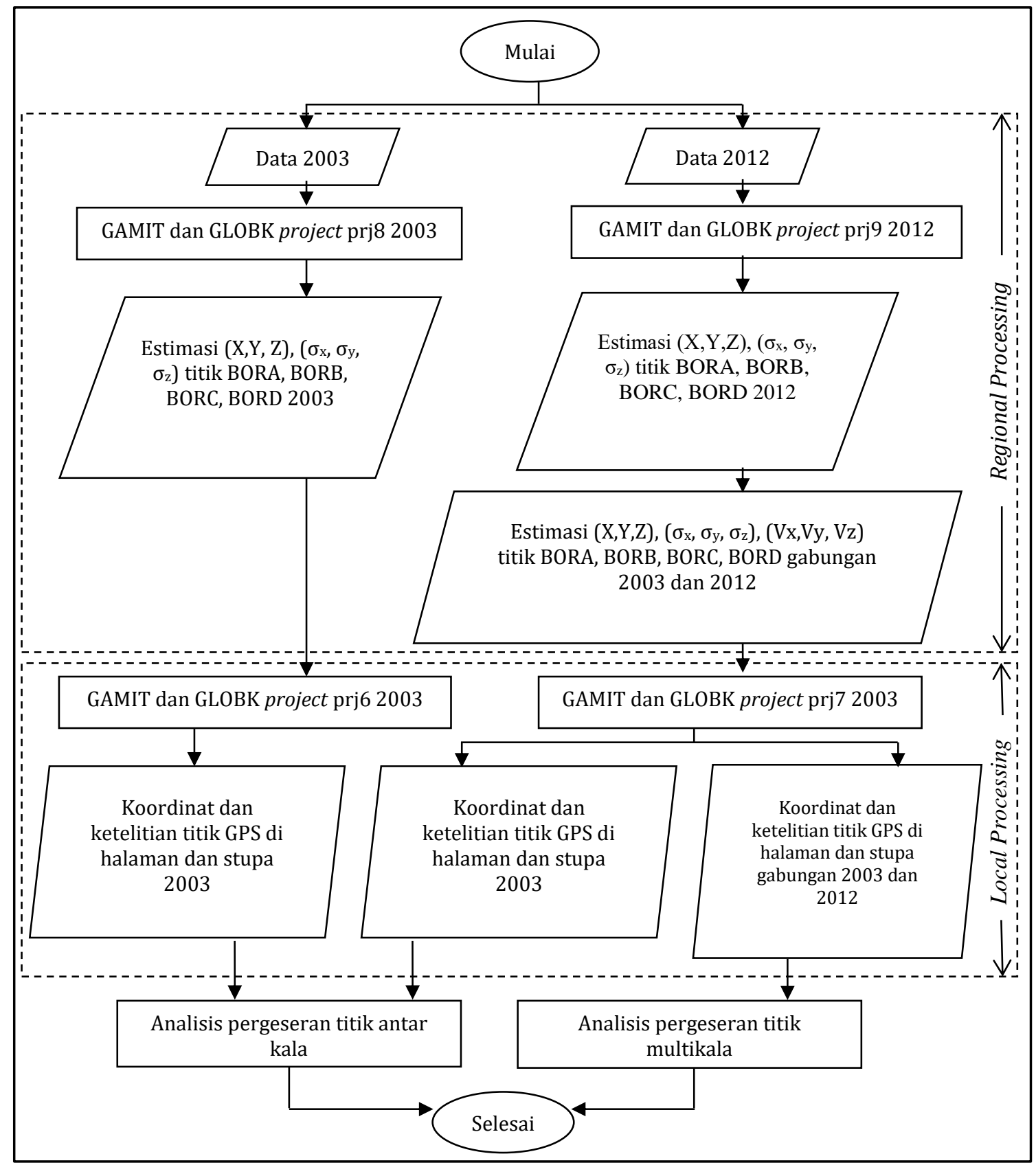

Gambar 2.2. Skema pengolahan data GPS 


\section{Hasil dan Pembahasan}

\subsection{Regional Processing}

Pada regional processing, peneliti menganalisis koordinat dan ketelitian titik-titik GPS tahun 2003, 2012, dan perbedaan koordinat mengacu pada ITRF 2000 dan 2008 yang dijelaskan secara berturut-turut pada Tabel 3.1.s.d Table 3.3.

Pada Tabel III.1, ketelitian posisi titik-titik tahun 2003 dalam fraksi 1 s.d $2 \mathrm{~mm}$ untuk X, Y dan Z. Hasil pengolahan jaring GPS tahun 2003, arah sumbu Y memiliki ketelitian yang lebih rendah dari arah yang lain, yaitu dalam fraksi milimeter. Hal ini disebabkan oleh lokasi Indonesia yang terletak di sekitar kawasan ekuator, sehingga sumbu Y menunjukkan arah vertikal. Komponen vertikal memiliki ketelitian lebih rendah karena faktor geometri satelit yang tidak memungkinkan untuk mengamati satelit yang terletak di bawah horison, sehingga kekuatan jaring untuk komponen vertikal menjadi lebih lemah jika dibandingkan dengan kekuatan jaring horizontal (Lestari, 2015). Jika dibandingkan dengan pengolahan menggunakan ITRF 2000, semua arah (X, Y, dan Z) pada penelitian ini memiliki ketelitian yang lebih tinggi. Pada saat menggunakan ITRF 2000, arah X, Y, dan Z titik BORA menunjukkan posisi koordinat -2183526,078 m, 5933589,514 , dan $839076,227 \mathrm{~m}$, secara berurutan. Posisi koordinat X, Y, dan Z titik BORB yaitu -2183339,661 m, 5933688,751 m, dan $838881,703 \mathrm{~m}$. Lalu titik BORC mempunyai posisi 2183587,712 m sebagai X, 5933636,938 m sebagai Y, dan 838627,516 sebagai Z. Sedangkan titik BORD, posisi koordinat arah X, Y, dan Y adalah -2183796,131 m, 5933529,883 m, dan $-838816,161$ m secara berturut-turut.

Koordinat dan ketelitian titik-titik GPS tahun 2012 yang terdapat pada Tabel III.2 , simpangan baku terkecil untuk posisi $\mathrm{X}$ dan $\mathrm{Z}$ adalah $1,07 \mathrm{~mm}$, sedangkan yang terbesar adalah 9,98. Simpangan baku terkecil posisi $Y$ adalah 4,34 $\mathrm{mm}$, sedangkan yang terbesar yaitu $23,48 \mathrm{~mm}$.

Transformasi datum geodetik ialah transformasi koordinat titik yang mengacu pada satu datum geodetik tertentu ke datum geodetik yang lain. Berkenaan dengan realisasi ITRS oleh ITRFyy, tiap versi atau seri ITRFyy merealisasikan ITRS (sistem atau datum geodetik yang sama) melalui himpunan koordinat dan laju pergeseran fiducial points (Fahrurrazi, 2011). Analisis perbedaan ITRF data tahun 2003 diawali dengan melakukan transformasi data tahun 2003 mengacu ITRF2000 ke ITRF2008.

Berdasarkan Tabel 3.3., nilai selisih sumbu X terkecil adalah pada titik BORC yaitu 0,01 mm pada pengolahan tahun 2003, sedangkan selisih terbesar terletak pada titik BORB yaitu 2,62 mm pada pengolahan tahun 2012. Nilai selisih sumbu Y terkecil adalah pada titik BORC yaitu 0,24 mm pada pengolahan 2003, sedangkan selisih terbesar terletak pada titik BORB yaitu $-5 \mathrm{~mm}$ pada pengolahan tahun 2012. Nilai selisih sumbu Z terkecil adalah pada titik BORB yaitu 0,01 mm pada pengolahan 2003, sedangkan selisih terbesar terletak pada titik BORB yaitu $-3.42 \mathrm{~mm}$ pada pengolahan tahun 2012. Jika dibandingkan dengan pengolahan menggunakan ITRF 2000, semua arah (X, Y, dan Z) pada penelitian ini memiliki ketelitian yang lebih tinggi.

Nilai selisih yang terdapat pada Tabel 3.3. mengindikasikan bahwa semua nilai hasil transformasi masih dalam rentang dua kali simpangan baku hasil olahan GAMIT dan GLOBK. Berdasarkan tabel tersebut, dapat dikatakan bahwa hasil transformasi data dan hasil olahan GAMIT dan GLOBK tidak berbeda signifikan. Artinya perbedaan posisi titik yang diolah mengacu ke ITRF 2000 dengan mengacu ke ITRF 2008 secara prinsip sesuai dengan besaran parameter transformasi antara kedua versi ITRF tersebut. Perbedaan koordinat posisi titik BORB yang lebih besar dari titik-titik yang lainnya disebabkan oleh kondisi lokasi titik BORB pada tahun 2012 berbeda dengan kondisi saat tahun 2003. Efek multipath yang besar disebabkan tumbuhnya pohon besar yang pada saat pengamatan pada tahun 2003 tidak ada.

\subsection{Local Processing}

Tahapan yang digunakan dalam local processing pada dasarnya memiliki langkah yang sama dengan regional processing. Jika pada regional processing, titik yang diolah adalah BORA, BORB, BORC, dan BORD serta menggunakan stasiun IGS untuk pengikatnya, maka pada local processing titik BORA, BORB, BORC, dan BORD digunakan sebagai titik pengikat untuk menghasilkan analisis terhadap titik yang terdapat pada halaman candi dan lorong stupa.

Posisi titik-titik GPS di taman beserta ketelitian hasil dari local processing tahun 2003 dalam sistem koordinat kartesi 3D adalah seperti pada Tabel 3.4. Nilai simpangan baku rerata untuk posisi $\mathrm{X}$ dan $\mathrm{Y}$ mendekati sama yaitu $1,13 \mathrm{~mm}$ dan $1,05 \mathrm{~mm}$, serta simpangan baku rerata terkecil pada posisi Z yaitu $0,36 \mathrm{~mm}$. Sementara itu, pada Tabel 3.5. memperlihatkan posisi dan ketelitian titik tahun 2012 pada sistem kartesi 3D. Nilai simpangan baku rerata pada jaring 2012 untuk posisi X dan Y mendekati sama yaitu 2,93 mm dan 3,16 mm, serta simpangan baku rerata terkecil pada posisi Z yaitu $1,05 \mathrm{~mm}$. Ketelitian yang diperoleh pada jaring 2003 dan 2012 dengan local processing sudah memenuhi syarat untuk studi deformasi Candi Borobudur.

Berdasarkan Tabel 3.6, nilai selisih sumbu X terkecil adalah pada titik BOR6 yaitu 0,30 $\mathrm{mm}$ pada pengolahan jaring 2003, sedangkan selisih terbesar terletak pada titik BORE yaitu $-3,76 \mathrm{~mm}$ pada pengolahan jaring 2012. Nilai selisih sumbu Y terkecil adalah pada titik BONW yaitu -0.21 mm, sedangkan selisih terbesar terletak pada titik BOSW yaitu $1,79 \mathrm{~mm}$, dimana keduanya merupakan pengolahan jaring 2012. Nilai selisih sumbu Z terkecil adalah pada pengolahan jaring tahun 2012 pada titik BOR3 yaitu 0,03 mm, sedangkan selisih terbesar terletak pada titik BONE yaitu -1,44 mm. Rentang nilai pada BOR6 lebih besar dari titik-titik pengamatan yang lain. BOR6 lebih besar karena titik tersebut berada di tepi lereng sisi timur laut bukit Candi Borobudur. 
Tabel 3.1. Koordinat dan ketelitian titik-titik GPS tahun 2003 hasil regional processing (Dewanto, 2016)

\begin{tabular}{llccrrr}
\hline \multicolumn{7}{c}{ Sistem Koordinat Kartesi 3D } \\
\hline Titik & $\mathbf{X ~ ( m )}$ & $\mathbf{Y ~ ( m )}$ & $\mathbf{Z}(\mathbf{m})$ & $\begin{array}{c}\boldsymbol{\sigma} \mathbf{x} \\
(\mathbf{m m})\end{array}$ & $\begin{array}{c}\boldsymbol{\sigma y} \\
(\mathbf{m m})\end{array}$ & $\begin{array}{c}\mathbf{\sigma z} \\
(\mathbf{m m})\end{array}$ \\
\hline BORA & $-2183526,076$ & 5933589,487 & $-839076,223$ & 1,10 & 1,10 & 1,00 \\
\hline BORB & $-2183339,658$ & 5933688,725 & $-838881,698$ & 0,82 & 2,51 & 1,09 \\
\hline BORC & $-2183587,709$ & 5933636,911 & $-838627,511$ & 1,08 & 1,31 & 1,01 \\
\hline BORD & $-2183796,129$ & 5933529,856 & $-838816,157$ & 1,21 & 1,99 & 1,02 \\
\hline
\end{tabular}

Tabel 3.2. Koordinat dan ketelitian titik-titik GPS tahun 2012 hasil Regional processing (Dewanto, 2016)

\begin{tabular}{|c|c|c|c|c|c|c|}
\hline \multicolumn{7}{|c|}{ Sistem Koordinat Kartesi 3D } \\
\hline Titik & $X(m)$ & $Y(m)$ & $\mathrm{Z}(\mathrm{m})$ & $\begin{array}{c}\sigma x \\
(\mathrm{~mm})\end{array}$ & $\begin{array}{c}\sigma y \\
(\mathrm{~mm})\end{array}$ & $\begin{array}{c}\sigma z \\
(\mathrm{~mm})\end{array}$ \\
\hline BORA & $-2183526,330$ & 5933589,327 & $-839076,304$ & 2,11 & 4,34 & 1,23 \\
\hline BORB & $-2183339,941$ & 5933688,642 & $-838881,787$ & 9,98 & 23,48 & 5,13 \\
\hline BORC & $-2183587,965$ & 5933636,740 & $-838627,575$ & 2,28 & 4,84 & 1,28 \\
\hline BORD & $-2183796,391$ & 5933529,781 & $-838816,221$ & 1,92 & 3,92 & 1,07 \\
\hline
\end{tabular}

Tabel 3.3. Perbedaan koordinat hasil regional processing mengacu ITRF 2000 dengan ITRF 2008 (Dewanto,2016)

\begin{tabular}{ccccccc}
\hline \multirow{2}{*}{ Titik } & \multicolumn{3}{c}{ Jaring 2003 } & \multicolumn{3}{c}{ Jaring 2012 } \\
\cline { 2 - 7 } & $\mathbf{d X} \mathbf{( m m})$ & $\mathbf{d Y} \mathbf{( m m})$ & $\mathbf{d Z} \mathbf{( m m})$ & $\mathbf{d X} \mathbf{( m m})$ & $\mathbf{d Y} \mathbf{( m m})$ & $\mathbf{d Z} \mathbf{( m m})$ \\
\hline BORA & $-0,05$ & $-0,38$ & $-0,03$ & 1,90 & 0,18 & $-0,11$ \\
\hline BORB & 0,64 & $-0,33$ & $-0,01$ & 4,97 & $-5,00$ & $-3,42$ \\
\hline BORC & $-0,01$ & 0,24 & $-0,03$ & 2,00 & $-0,90$ & 0,01 \\
\hline BORD & $-0,24$ & 0,29 & 0,07 & 1,08 & 2,41 & $-0,04$ \\
\hline
\end{tabular}

Tabel 3.4. Koordinat dan ketelitian titik-titik GPS tahun 2003 hasil local processing (Dewanto,2016)

Sistem Koordinat Kartesi 3D

\begin{tabular}{lcccrrr}
\hline Titik & $\mathbf{X}(\mathbf{m})$ & $\mathbf{Y}(\mathbf{m})$ & $\mathbf{Z}(\mathbf{m})$ & $\begin{array}{c}\boldsymbol{\sigma x} \\
(\mathbf{m m})\end{array}$ & $\begin{array}{c}\boldsymbol{\sigma y} \\
(\mathbf{m m})\end{array}$ & $\begin{array}{c}\boldsymbol{\sigma Z} \\
(\mathbf{m m})\end{array}$ \\
\hline BOR1 & $-2183592,680$ & 5933607,340 & $-838931,019$ & 1,22 & 1,09 & 0,31 \\
\hline BOR3 & $-2183522,488$ & 5933643,235 & $-838859,487$ & 1,35 & 1,20 & 0,38 \\
\hline BOR6 & $-2183659,542$ & 5933600,263 & $-838808,270$ & 2,35 & 2,04 & 0,97 \\
\hline BORE & $-2183494,422$ & 5933668,606 & $-838751,388$ & 1,56 & 1,61 & 0,68 \\
\hline BONW & $-2183582,392$ & 5933643,285 & $-838839,039$ & 1,13 & 0,85 & 0,24 \\
\hline BONE & $-2183623,715$ & 5933627,999 & $-838839,481$ & 1,30 & 1,27 & 0,35 \\
\hline BOSE & $-2183621,599$ & 5933622,554 & $-838883,492$ & 1,34 & 1,20 & 0,42 \\
\hline BOSW & $-2183579,953$ & 5933637,779 & $-838884,463$ & 1,34 & 1,17 & 0,36 \\
\hline
\end{tabular}

Tabel 3.5. Posisi dan ketelitian titik-titik GPS tahun 2012 hasil local processing kartesi 3D (Dewanto, 2016)

\begin{tabular}{lcccrrr}
\hline Titik & $\mathbf{X}(\mathbf{m})$ & $\mathbf{Y ~ ( m )}$ & $\mathbf{Z}(\mathbf{m})$ & $\begin{array}{c}\mathbf{\sigma x} \\
(\mathbf{m m})\end{array}$ & $\begin{array}{c}\boldsymbol{\sigma} \mathbf{( m m} \\
(\mathbf{m m})\end{array}$ & $\begin{array}{c}\mathbf{\sigma Z} \\
(\mathbf{m m})\end{array}$ \\
\hline BOR1 & $-2183592,928$ & 5933607,304 & $-838931,108$ & 1,97 & 1,67 & 0,56 \\
\hline BOR3 & $-2183522,697$ & 5933643,085 & $-838859,549$ & 2,31 & 1,88 & 0,70 \\
\hline BOR6 & $-2183659,751$ & 5933600,085 & $-838808,288$ & 7,44 & 7,60 & 3,22 \\
\hline BORE & $-2183494,625$ & 5933668,425 & $-838751,451$ & 2,44 & 2,18 & 0,89 \\
\hline BONW & $-2183582,588$ & 5933643,106 & $-838839,101$ & 2,46 & 2,14 & 0,75 \\
\hline BONE & $-2183623,900$ & 5933627,818 & $-838839,535$ & 3,28 & 2,76 & 1,01 \\
\hline BOSE & $-2183621,842$ & 5933622,495 & $-838883,564$ & 2,28 & 2,09 & 0,74 \\
\hline BOSW & $-2183580,144$ & 5933637,597 & $-838884,518$ & 2,75 & 2,30 & 0,86 \\
\hline
\end{tabular}


Tabel 3.6. Selisih koordinat hasil transformasi dengan olahan GAMIT dan GLOBK (Dewanto, 2016)

\begin{tabular}{ccccccc}
\hline \multirow{2}{*}{ Titik } & \multicolumn{3}{c}{ Jaring 2003 } & \multicolumn{3}{c}{ Jaring 2012 } \\
\cline { 2 - 7 } & $\mathbf{d X ~ ( m m )}$ & $\mathbf{d Y}(\mathbf{m m})$ & $\mathbf{d Z} \mathbf{( m m )}$ & $\mathbf{d X}$ & $\mathbf{d Y}$ & $\mathbf{d Z}$ \\
$\mathbf{~ B O R 1 ~}$ & $-0,75$ & 0,86 & 0,49 & $-0,82$ & 1,12 & 0,88 \\
\hline BOR3 & $-0,59$ & $-0,72$ & 0,29 & $-0,42$ & 1,50 & 0,03 \\
\hline BOR6 & 0,30 & $-1,11$ & $-0,60$ & $-0,68$ & 1,55 & 1,28 \\
\hline BORE & $-1,99$ & $-0,52$ & $-0,60$ & $-3,76$ & $-1,37$ & 0,25 \\
\hline BONW & $-1,00$ & 0,96 & 0,40 & $-2,41$ & $-0,21$ & $-0,07$ \\
\hline BONE & 1,99 & $-0,91$ & $-0,08$ & 1,96 & $-1,24$ & $-1,44$ \\
\hline BOSE & 2,09 & $-1,13$ & $-0,38$ & $-1,84$ & 1,60 & $-0,08$ \\
\hline BOSW & $-2,62$ & $-1,32$ & 0,11 & 1,43 & 1,79 & 0,07 \\
\hline
\end{tabular}

\subsection{Perbandingan Ketelitian}

Perbandingan ketelitian posisi dalam sistem kartesi (X, Y, Z) hasil local processing untuk setiap kala ditampilkan secara grafis pada Gambar 3.1. s.d 3.3.

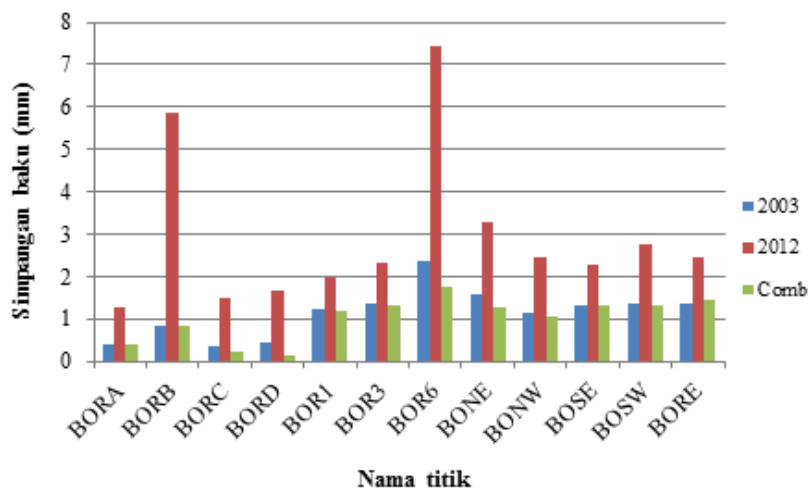

Gambar 3.1. Perbandingan ketelitian posisi titik arah sumbu X pada local processing

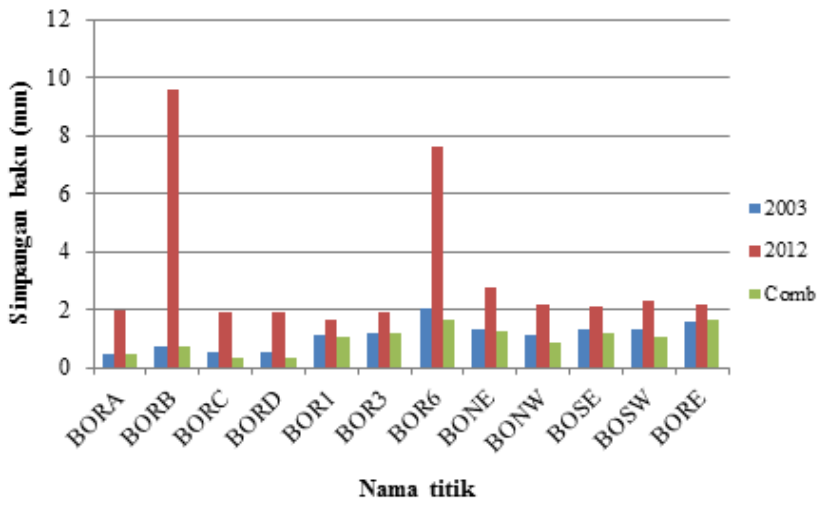

Gambar 3.2. Perbandingan ketelitian posisi titik arah sumbu Y pada local processing

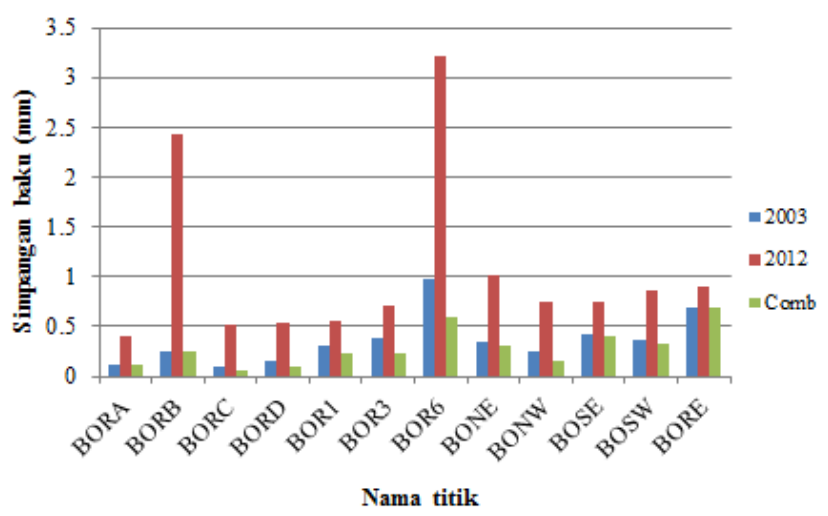

Gambar 3.3. Perbandingan ketelitian posisi titik arah sumbu Z pada local processing

Ilustrasi tersebut menjelaskan bahwa ketelitian posisi terbaik diperoleh dari gabungan data pengamatan tiap kala, meskipun perbedaan ketelitian untuk masing-masing titik pada setiap kala pengamatan juga kecil (dalam fraksi submilimeter), kecuali di titik BORB dan BOR6. Seperti yang telah dijelaskan sebelumnya, perbedaan lingkungan di sekitar titik BORB pada saat pengukuran kala 2003 dan 2012 menyebabkan penyimpangan yang cukup besar pada titik BORB. Perbedaan agak mencolok tampak pada titik BORB tahun 2012. Simpangan baku titik BOR6 sedikit lebih besar karena lokasi titik BOR6 yang berada di tepi lereng sisi timur laut bukit candi. Secara umum ketelitian hasil dari pengolahan data pengamatan Candi Borobudur mengacu ke ITRF 2008 lebih teliti jika dibandingkan dengan mengacu ke 2000 yang telah dilakukan pada penelitian sebelumnya.

\subsection{Analisis Pergeseran Antar Kala}

Analisis pergeseran dua kala dicoba untuk data pengamatan 2003 dan 2012. Metode yang digunakan adalah dengan menghitung selisih estimasi posisi/ koordinat titik-titik GPS tahun 2003 dan 2012. Gambaran pergeseran yang lebih jelas pada analisis ini digunakan koordinat toposentrik GAMIT (N, E, U). Hasil dari analisis pergeseran horizontal dapat dilihat pada Tabel 3.7. serta pola pergeseran dapat dilihat pada Gambar 3.4. 
Tabel 3.7. Pergeseran horizontal tahun 2003 dan 2012

\begin{tabular}{|l|c|r|r|r|}
\hline Titik & $\begin{array}{c}\mathbf{d E} \\
\mathbf{( m m}\end{array}$ & $\begin{array}{c}\mathbf{d N} \\
\mathbf{( m m})\end{array}$ & $\mathbf{D} \mathbf{( m m )}$ & \multicolumn{1}{c|}{ Alfa() } \\
\hline BORA & 270,36 & $-90,73$ & 285,18 & 108,5512 \\
\hline BORB & 277,12 & $-103,61$ & 295,86 & 110,5002 \\
\hline BORC & 275,71 & $-74,01$ & 285,47 & 105,0261 \\
\hline BORD & 260,29 & $-84,78$ & 273,75 & 108,0417 \\
\hline BOR1 & 271,10 & $-95,08$ & 287,29 & 109,3274 \\
\hline BOR3 & 273,09 & $-84,10$ & 285,75 & 107,1165 \\
\hline BOR6 & 288,44 & $-36,77$ & 290,77 & 97,2655 \\
\hline BONE & 266,80 & $-85,40$ & 280,14 & 107,7493 \\
\hline BONW & 275,70 & $-86,77$ & 289,03 & 107,4700 \\
\hline BOSE & 270,90 & $-84,79$ & 283,86 & 107,3791 \\
\hline BOSW & 274,90 & $-84,48$ & 287,58 & 107,0829 \\
\hline BORE & 270,39 & $-88,00$ & 284,35 & 108,0278 \\
\hline Rerata & 250,75 & $-76,76$ & 285,75 & 106,9615 \\
\hline
\end{tabular}

Nilai pergeseran horizontal rerata untuk kurun waktu 2003 dan 2012 adalah $261 \mathrm{~mm}$ dengan arah vektor pergeseran (alfa/ azimuth) ke tenggara (SE).

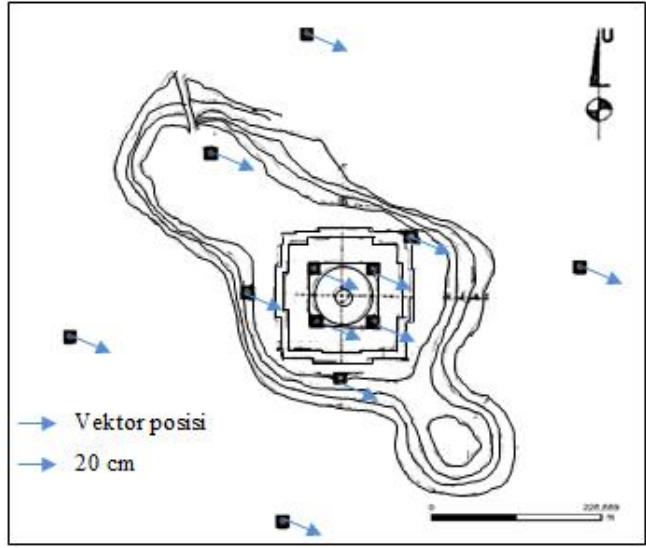

Gambar 3.4. Pola pergeseran titik-titik pengamatan GPS tahun 2003 dan 2012

Tabel 3.8. Uji signifikansi data local processing tahun 2003 dan 2012 menggunakan ITRF2008

\begin{tabular}{|c|c|c|c|c|c|c|c|c|c|}
\hline Titik & $\mathbf{x}_{2}-\mathbf{x}_{1}$ & Uji t (X) & $\begin{array}{c}\text { Hasil Uji } \\
(\mathrm{X})\end{array}$ & $\mathbf{y}_{2}-\mathbf{y}_{1}$ & Uji t (Y) & $\begin{array}{c}\text { Hasil Uji } \\
(\mathrm{Y})\end{array}$ & $\mathbf{z}_{2}-\mathbf{z}_{1}$ & Uji t (Z) & $\begin{array}{c}\text { Hasil Uji } \\
\text { (Z) }\end{array}$ \\
\hline BORA & 0,210 & $-160,945$ & Ditolak & 0,144 & $-71,471$ & Ditolak & 0,058 & $-137,348$ & Ditolak \\
\hline BORB & 0,248 & $-41,828$ & Ditolak & 0,062 & $-6,484$ & Ditolak & 0,081 & $-33,145$ & Ditolak \\
\hline BORC & 0,211 & $-140,026$ & Ditolak & 0,144 & $-72,040$ & Ditolak & 0,039 & $-75,701$ & Ditolak \\
\hline BORD & 0,238 & $-140,031$ & Ditolak & 0,048 & $-24,275$ & Ditolak & 0,066 & $-119,103$ & Ditolak \\
\hline BOR1 & 0,248 & $-104,528$ & Ditolak & 0,037 & $-18,668$ & ditolak & 0,090 & $-129,680$ & Ditolak \\
\hline BOR3 & 0,208 & $-74,905$ & Ditolak & 0,151 & $-66,163$ & ditolak & 0,062 & $-72,581$ & Ditolak \\
\hline BOR6 & 0,209 & $-26,532$ & Ditolak & 0,179 & $-22,751$ & ditolak & 0,019 & $-5,770$ & Ditolak \\
\hline BORE & 0,199 & $-65,015$ & Ditolak & 0,180 & $-66,282$ & ditolak & 0,063 & $-55,894$ & Ditolak \\
\hline BONW & 0,194 & $-63,232$ & Ditolak & 0,178 & $-70,479$ & ditolak & 0,063 & $-67,632$ & Ditolak \\
\hline BONE & 0,187 & $-50,053$ & Ditolak & 0,180 & $-57,667$ & ditolak & 0,053 & $-46,002$ & Ditolak \\
\hline BOSE & 0,241 & $-80,661$ & Ditolak & 0,061 & $-23,072$ & ditolak & 0,072 & $-74,585$ & Ditolak \\
\hline BOSW & 0,192 & $-58,991$ & Ditolak & 0,185 & $-67,785$ & ditolak & 0,055 & $-53,792$ & Ditolak \\
\hline
\end{tabular}

Tabel 3.9. Uji signifikansi data local processing tahun 2003 dan 2012 menggunakan hasil transformasi ITRF2000 ke ITRF 2008

\begin{tabular}{|c|c|c|c|c|c|c|c|c|c|}
\hline Titik & $\mathbf{X}_{2}-\mathbf{x}_{1}$ & Uji t (X) & $\begin{array}{c}\text { Hasil Uji } \\
\text { (X) }\end{array}$ & $\mathbf{y}_{2}-y_{1}$ & Uji t (Y) & $\begin{array}{c}\text { Hasil Uji } \\
\text { (Y) }\end{array}$ & $\mathbf{z}_{2}-\mathbf{z}_{1}$ & Uji t (Z) & $\begin{array}{c}\text { Hasil Uji } \\
\text { (Z) }\end{array}$ \\
\hline BORA & 0,210 & $-160,945$ & Ditolak & 0,144 & $-71,471$ & Ditolak & 0,058 & $-137,348$ & Ditolak \\
\hline BORB & 0,248 & $-41,828$ & Ditolak & 0,062 & $-6,484$ & Ditolak & 0,081 & $-33,145$ & Ditolak \\
\hline BORC & 0,211 & $-140,026$ & Ditolak & 0,144 & $-72,040$ & Ditolak & 0,039 & $-75,701$ & Ditolak \\
\hline BORD & 0,238 & $-140,031$ & Ditolak & 0,048 & $-24,275$ & Ditolak & 0,066 & $-119,103$ & Ditolak \\
\hline BOR1 & 0,248 & $-104,528$ & Ditolak & 0,037 & $-18,668$ & ditolak & 0,090 & $-129,680$ & Ditolak \\
\hline BOR3 & 0,208 & $-74,905$ & Ditolak & 0,151 & $-66,163$ & ditolak & 0,062 & $-72,581$ & Ditolak \\
\hline B0R6 & 0,209 & $-26,532$ & Ditolak & 0,179 & $-22,751$ & ditolak & 0,019 & $-5,770$ & Ditolak \\
\hline BORE & 0,199 & $-65,015$ & Ditolak & 0,180 & $-66,282$ & ditolak & 0,063 & $-55,894$ & Ditolak \\
\hline BONW & 0,194 & $-63,232$ & Ditolak & 0,178 & $-70,479$ & ditolak & 0,063 & $-67,632$ & Ditolak \\
\hline BONE & 0,187 & $-50,053$ & Ditolak & 0,180 & $-57,667$ & ditolak & 0,053 & $-46,002$ & Ditolak \\
\hline BOSE & 0,241 & $-80,661$ & Ditolak & 0,061 & $-23,072$ & ditolak & 0,072 & $-74,585$ & Ditolak \\
\hline BosW & 0,192 & $-58,991$ & Ditolak & 0,185 & $-67,785$ & ditolak & 0,055 & $-53,792$ & Ditolak \\
\hline
\end{tabular}


3.6. Analisis Uji Signifikansi Pergeseran Posisi Titik Pengamatan GPS

Uji signifikansi pergeseran posisi titik pengamatan GPS dilakukan dengan membandingkan nilai koordinat kartesi pada komponen X, Y dan Z pada 12 titik pengamatan GPS Candi Borobudur tahun 2003 dan 2012, baik mengacu ITRF 2008 hasil pengolahan GAMIT maupun hasil transformasi. Uji ini menggunakan proses hitungan kuadrat terkecil (Ghilani, 2010 and Kuang, 1991). Tabel 3.8. dan Tabel 3.9. secara berturut-turut memperlihatkan uji signifikansi data local processing tahun 2003 dan 2012 menggunakan ITRF2008 serta uji signifikansi data local processing tahun 2003 dan 2012 menggunakan hasil transformasi ITRF2000 ke ITRF 2008.

Pada hasil uji tersebut, semua stasiun pada semua arah sumbu X, Y, dan Z menunjukkan bahwa nilai t-hitungan melebihi $\pm 1,960$ sehingga semua stasiun dinyatakan ditolak yang mengindikasikan bahwa nilai koordinat komponen X, Y, dan Z tahun 2003 dan 2012 berbeda secara signifikan (ada pergeseran titik signifikan). Berdasarkan hasil uji didapatkan pula bahwa besar pergeseran dan polanya mendekati sama jika dibandingkan dengan pergeseran hasil olahan mengacu ke ITRF 2000.

Berdasarkan hasil penelitian, penggunaan kerangka acuan ITRF 2008 pada analisis pergeseran posisi Candi Borobudur dengan data 2003 dan 2012 meningkatkan ketelitian dengan selisih terbesar yaitu $5 \mathrm{~mm}$. Hasil ini sesuai dengan hipotesis yang diperkirakan di awal penelitian.

\section{Kesimpulan}

Nilai selisih posisi dan ketelitian baik dalam regional processing maupun local processing, mengindikasikan bahwa semua nilai hasil transformasi dari ITRF $2000 \mathrm{ke}$ ITRF 2008 masih dalam rentang dua kali simpangan baku hasil olahan GAMIT dan GLOBK. Berdasarkan tabel tersebut, dapat dikatakan bahwa hasil transformasi data dan hasil olahan GAMIT dan GLOBK tidak berbeda signifikan. Nilai pergeseran horizontal rerata untuk kurun waktu 2003 dan 2012 adalah $261 \mathrm{~mm}$ dengan arah vektor pergeseran (alfa/ azimuth) ke tenggara (SE). Secara umum ketelitian hasil dari pengolahan data pengamatan Candi Borobudur mengacu ke ITRF 2008 lebih teliti jika dibandingkan dengan mengacu ke ITRF2000 yang telah dilakukan pada penelitian sebelumnya.

\section{Pernyataan Konflik Kepentingan}

Penulis menyatakan tidak ada konflik kepentingan dalam artikel ini (The authors declare no competing interest).

\section{Referensi}

Abidin, H.Z. (1995). Penentuan Posisi dengan GPS dan Aplikasinya. PT Pradnya Paramita, Jakarta, Indonesia. ISBN: 979-408-377-1.

Altamimi, Z., Collilieux, X., \& Metivier, L. (2012). Analysis and results of ITRF2008. (IERS Technical Note; 37) Frankfurt am Main: Verlag des Bundesamts für
Kartographie und Geodäsie, 54 pp., ISBN 978-386482-046-5.

Altamimi, Z, Rebischung, P., Métivier, L., \& Collilieux, X. (2016). ITRF2014: A new release of the International Terrestrial Reference Frame modeling nonlinear station motions. Journal of Geophysical Research: Solid Earth, 121, 6109-6131, https://doi.org/10.1002/2016JB013098

Boucher, C., Altamimi, Z., Sillard, P., \& Feissel-Vernier, M., (2004). The ITRF2000. (IERS Technical Note; 31) Frankfurt am Main: Verlag des Bundesamts für Kartographie und Geodäsie, 289 pp., ISBN 389888-881-9.

Dewanto, B.G. (2016). Analisis Pergeseran Titik Jaring Pemantau Candi Borobudur Mengacu ke ITRF 2008 berdasarkan Data Pengamatan GPS pada Tahun 2003 dan 2012. Universitas Gadjah Mada.

Fakhrurrazi, D. (2011). Sistem Acuan Geodetik dari Bigbang sampai Kerangka Acuan Terestrial. Gadjah Mada University Press, Bulaksumur, Yogyakarta. ISBN: 9794207624 .

Ghilani., C.D. (2010). Adjustment Computation Spatial Data Analysis. 5th Edition, John Wiley \& Sons, Inc, New Jersey, USA. ISBN: 978-1-119-38598-1.

Herring, T. A., King, R. W., Floyd, M. A., \& McClusky, S. C. (2015). Introduction to GAMIT/GLOBK. Department of Earth, Atmospheric, and Planetary Science, Massachusetts Institute of Technology. Retrieved from http://wwwgpsg.mit.edu/ simon/gtgk/Intro_GG.pdf.

Isnaini, E.L. \& Lestari, D. (2018). Comparison of Horizontal Displacement from Horizontal Control Network Adjustment Result Using Observation Model and Time-Variant Methods. Journal of Geospatial Information Science and Engineering, 1(1), 27-34. https://doi.org/10.22146/jgise.38472.

Kuang, S. (1991). Optimization and Design of Deformation Monitoring Schemes. University of New Brunswick.

Lestari, D. (2015), Analisis Stabilitas Candi Borobudur Berdasar Integrasi Data Pengamatan GPS dan Terestris Jaring Pemantau Deformasi Candi. Universitas Gadjah Mada.

Lestari, D., Yulaikhah, \& Sari, R.I. (2018). Time Variant Adjustment for The Solution of Control Point Unstability in Deformation Analysis of Borobudur Vertical Deformation Monitoring Network. Journal of Geospatial Information Science and Engineering, $1(1)$, 43-50. https://doi.org/10.22146/jgise.38590.

Ma'ruf, B., Djawahir, Sunantyo, A., Parseno, Widjajanti, N., Yulaikhah, Nasihun, M., Armeinus, F., \& Zaim, M. (2001). Pengadaan Jaring Titik Kontrol Deformasi dengan Menggunakan GPS di Kawasan Candi Borobudur. Jurnal Surveying \& Geodesi, Vol. XI, No. 2, Mei 2001, Jurusan Teknik Geodesi, Institut Teknologi Bandung, Indonesia, 35-43.

Muryamto, R., Taftazani, M.I., Yulaikhah, Cahyono, B.K., \& Prasidya, A.S. (2018). Development and Definition of Prambanan Temple Deformation Monitoring 
Control Points. Journal of Geospatial Information Science and Engineering, 1(2), 81-86. https://doi.org/10.22146/jgise.40788.

Wei, Z., Shuang, Z., Bo, Y., Yanqiang, W., Zhiguang, L., \& Xiangang, M. (2013). Effect of the Differences between the ITRF2000 and ITRF2005 Models in GNSS Data Processing. Geodesy and Geodynamics,
$4(4)$,

46-50.

https://doi.org/10.3724/SP.J.1246.2013.04046.

Widjajanti, N. (2010). Deformation Analysis of Offshore Platform using GPS Technique and its Application in Structural Integrity Assessment. Universiti Teknologi PETRONAS. 